\title{
SAHAM SYARIAH; TEORI DAN IMPLEMENTASI
}

\author{
Choirunnisak \\ Dosen Perbankan Syariah STEBIS IGM Palembang \\ Email: Choirunnisak-umar@stebisigm.ac.id
}

\begin{abstract}
ABSTRAK
Penelitian ini membahas saham syariah, Perbedaan mendasar antara saham konvensional dan saham syari'ah adalah saham syari'ah harus masuk ke dalam JII (Jakarta islamic Index). Mekanisme operasional dari saham syari'ah terdiri dari proses emisi dan perdagangan di bursa efek. Perdagangan di bursa efek ini terdiri dari perdagangan di pasar primer dan pasar sekunder. Pada pasar primer, harga saham bersifat pasti. Berbeda dengan pasar sekunder yang harga sahamnya bersifat fluktuatif berdasarkan demand dan suply serta perusahaan yang menerbitkan saham sendiri.
\end{abstract}

Kata Kunci: Saham Syariah, Pasar Modal, Islam

\section{DASAR PEMIKIRAN}

Pasar modal pada umumnya merupakan suatu tempat bertemunya para penjual dan pembeli untuk melakukan transaksi dalam rangka memperoleh modal. Penjual dalam pasar modal merupakan perusahaan yang membutuhkan modal (emiten) sedangkan pihak yang ingin membeli modal diperusahaan dengan tujuan untuk memperoleh keuntungan disebut sebagai investor (Soemitra, 2009: 111). Pasar modal syari'ah adalah pasar modal yang menerapkan prinsip-prinsip syari'ah dalam kegiatan transaksi ekonominya. Ada beberapa instrumen syari'ah pada pasar modal ini, seperti saham syari'ah, obligasi syari'ah, reksadana syari'ah, dan lain sebagainya. Pada makalah ini akan dibahas mengenai salah satu instrumen saja, yakni saham syari'ah.

Saham merupakan surat berharga yang sudah banyak dikenal oleh masyarakat. Saham merupakan surat berharga keuangan yang diterbitkan oleh suatu perusahaan saham patungan sebagai suatu alat untuk meningkatkan modal jangka panjang (Manan, 2012: 283-284).

Pengertian saham syari'ah menurut OJK adalah surat berharga bukti penyertaan modal kepada perusahaan dan dengan bukti penyertaan tersebut pemegang saham berhak untuk mendapatkan bagian hasil dari usaha perusahaan tersebut. Konsep penyertaan modal dengan hak bagian hasil usaha ini merupakan konsep yang tidak bertentangan dengan prinsip syariah. Prinsip syariah mengenal konsep ini sebagai 
kegiatan musyarakah atau syirkah. Berdasarkan analogi tersebut, maka secara konsep saham merupakan efek yang tidak bertentangan dengan prinsip syariah. Namun demikian, tidak semua saham yang diterbitkan oleh Emiten dan Perusahaan Publik dapat disebut sebagai saham syariah.c Berangkat dari permasalahan di atas penulis tertarik ingin menulis saham syariah.

Penelitian ini merupakan penelitian jenispustaka (libraty research) yang menitikberatkan pada pengelolaan data secara kualitatif dengan metodea nalisis data menggunakan metode deskriptif-analisis. Penelitian ini bertujuan untuk menggambarkan atau membeberkan apa yang terjadi sekarang (Arikunto, 2002:9), dan mengeksplorasi penomena-penomena yang tidak dapat dikuantifikasikan (Satori danKomariah, 2009:23). Selain itu, deskriptif penting karena merupakan metode analisis data yang berfungsi untuk menjelaskan suatu pikiran (fakta) sehingga dapat diterima secara rasional (Surabaya, 2007:18).

\section{TINJAUAN PUSTAKA}

Skripsi Adisi Sharesia Rusena, Analisis Fundamental Dan Teknikal Padasaham Syariah Di Indonesia (Studi Empiris: Perusahaan yang Masuk dalam JII dan ISSI di Bursa Efek Indonesia Tahun 2011-2015). Tujuan dari penelitian ini adalah untuk mengetahui pengaruh analisis fundamental dan teknikal pada saham syariah di Indonesia, apakah dengan menggabungkan kedua bentuk analisis ini dapat menghasilkan sebuah prediksi yang lebih tepat terhadap pergerakan harga saham syariah di Indonesia. Data yang digunakan dalam penelitian ini adalah data tahunan dari 2011 sampai 2014. Teknik sampling yang digunakan dalam penelitian ini adalah purposive sampling. Saham syariah yang terpilih sebagai objek penelitian sebanyak 91 saham syariah yang masih aktif dan selalu ada selama lima tahun penelitian untuk dianalisis sebagai sampel. Total sampel penelitian adalah 364 laporan keuangan dan laporan tahunan. Penelitian ini menggunakan metode analisis regresi data panel dengan menggunakan software Eviews 8.0, SPSS versi 20.0 dan Microsoft Excel 2010. Variabel dependen dalam penelitian ini adalah harga saham syariah sedangkan variabel independen adalah BVPS, PER, EPS, FEPS, harga saham masa lalu dan dua variabel dummy yang merupakan tren harga saham dengan level signifikansi sebesar 5\%. Hasil penelitian menunjukkan bahwa pada analisis fundamental yaitu BVPS, EPS dan FEPS 
dapat memberikan pengaruh terhadap harga saham syariah, sedangkan PER tidak dapat mempengaruhi harga saham syariah. Ketika analisis fundamental terintegrasi dengan analisis teknikal, BVPS tidak lagi positif terhadap harga saham. Pada analisis teknikal, hanya harga saham masa lalu yang dapat memberikan pengaruh terhadap harga saham syariah, sedangkan dua variabel dummy yang merupakan tren harga saham tidak memberikan pengaruh terhadap harga sahamsyariah.

Skripsi Ayu Syintia yang berjudul analisi integrasi indeks harga saham syariah pada pasar modal syariah Indonesia, Malaysia, China, danJepang (priode Mei 2011Desember 2016. penelitian ini adalah apakah Dow Jones Islamic World Malaysia Index (DJMY25D), Dow Jones Islamic Market China (DJICHKU) dan Dow Jones Islamic Market Jepang Index (DJIJP) secara simultan dan parsial terintegrasi terhadap Indeks Saham Syariah Indonesia(ISSI.JK).

Dalam hal ini penulis menggunakan beberapa teori diantaranya yaitu teori tentang investasi, pasar modal, pasar modal syariah, DJIM (Dow Jones Islamic Market), integrasi pasar modal dan indeks harga saham.

Penelitian ini menggunakan data kuantitatif yaitu data yang diukur dalam suatu skala numerik (angka). Periode penelitian tahun 2011-2016. Variabel independen dari penelitian ini adalah DJMY25D, DJICHKU dan DJIJP. Sedangkan variabel dependennya adalah ISSI.JK. Data yang digunakan dalam penelitian ini adalah data sekunder, yaitu indeks harga closing price diakhir bulan. Metode analisis yang digunakan adalah analisis regresi linier berganda dengan terlebih dahulu melakukan uji asumsi klasik. Untuk mengetahui pengaruh secara simultan digunakan uji $\mathrm{F}$ dan untuk mengatuhi pengaruh secara parsial digunakan uji t.

Hasil penelitian menunjukkan bahwa secara simultan DJMY25D, DJICHKU dan DJIJP mempunyai pengaruh terhadap ISSI.JK. Namun secara parsial yang berpengaruh positif terhadap ISSI.JK hanya DJMY25D, sedangkan DJICHKU dan DJIJP berpengaruh negatif terhadap ISSI.JK. DJMY25D berpengaruh positif dan signifikan terhadap ISSI.JK artinya jika profitabilitas DJMY25D meningkat maka ISSI.JK meningkat. Akan tetapi berbeda dengan hipotesis yang diajukan, DJICHKU berpengaruh positif terhadap ISSI.JK. Sedangkan DJIJP berpengaruh negatif. Berdasarkan hasil uji determinasi besarnya nilai Adjusted R Square adalah 0.207, hal ini berarti 20,7\% variasi ISSI.JK dapat dijelaskan oleh variasi dari tiga 
variabel yang berpengaruh terhadap ISSI.JK. sedangkan sisanya $(100 \%-20.7 \%=$ $79,3 \%$ ) dijelaskan oleh variabel lain yang tidak dimasukkan dalam model persamaan regresi.

\section{PEMBAHASAN}

\section{Pengertian Saham Syari’ah}

Saham atau stocks adalah surat bukti atau tanda kepemilikan bagian modal pada suatu perusahaan terbatas. Pemilik saham sekaligus juga merupakan pemilik perusahaan. Semakin besar saham yang dimiliki maka semakin pula kekuasaannya terhadap perusahaan tersebut. Keuntungan yang diperoleh dari perusahaan tersebut dinamakan dividen. Pembagian dividen ini nantinya ditetapkan pada penutupan laporan keuangan berdasarkan rapat umum pemegang saham (Soemitra, 2009, 137).

Saham juga merupakan sertifikat yang menunjukkan bukti kepemilikan suatu perusahaan yang pemegang sahamnya memiliki hak atas klaim dan aktiva perusahaan tersebut (Yuliana, 2010: 59). Wujud saham adalah selembar kertas yang menerangkan bahwa pemilik kertas tersebut adalah pemilik perusahaan yang menerbitkan surat berharga (Rivai, dkk, 2014: 246-247).

Saham syari'ah adalah sertifikat yang menunjukkan bukti kepemilikan suatu perusahaan yang diterbitkan oleh emiten yang kegiatan usaha maupun cara pengelolaannya tidak bertentangan dengan prinsip syari'ah. Saham merupakan surat berharga yang merepresentasikan penyertaan modal ke dalam suatu perusahaan. Sementara dalam prinsip syari'ah, penyertaan modal dilakukan pada perusahaanperusahaan yang tidak melanggar prinsip syari'ah, seperti perjudian, riba, serta memproduksi barang yang diharamkan. Penyertaan modal dalam bentuk saham tersebut dapat dilakukan berdasarkan akad musyarakah dan mudharabah. Akad musyarakah pada umumnya dilakukan pada perusahaan yang bersifat privat, sedangkan akad mudharabah umumnya dilakukan pada saham perusahaan publik (Soemitra, 2009: 138). Saham menurut Dewan Syari'ah Nasional didefinisikan sebagai suatu bukti kepemilikan atas suatu perusahaan yang memenuhi kriteria syariah dan tidak termasuk saham yang memiliki hak-hak istimewa (Yuliana, 2010: $71)$. 


\section{Landasan Hukum Saham Syariah}

Hukum mengenai saham syari'ah belum ada secara jelas dan pasti di dalam alQur'an dan hadits. Maka para ulama dan fuqaha kontemporer berusaha untuk menemukan rumusan kesimpulan hukum tersendiri dengan cara ijtihad mengenai saham ini. Para fuqaha kontemporer berselisih pendapat dalam memperlakukan salam. Sebagian membolehkan transaksi jual beli saham dan ada juga yang tidak membolehkan.

Menurut Wahbah al Zuhaili, bermuamalah dengan (melakukan kegiatan transaksi atas) saham hukumnya boleh, karena pemilik saham adalah mitra dalam perseroan sesuai dengan saham yang dimilikinya. Pendapat para ulama yang memperbolehkan jual beli saham serta pengalihan kepemilikan porsi suatu surat berharga berdasarkan pada ketentuan bahwa semua itu disepakati dan diizinkan oleh pemilik porsi lain dari suatu surat berharga. Keputusan Muktamar ke-7 Majma' Fiqh Islami tahun 1992 di Jeddah juga menyatakan bahwa boleh menjual dan menjaminkan saham dengan tetap memperhatikan peraturan yang berlaku pada perseroan (Rivai, dkk, 2014: 247). Fatwa Dewan Syari'ah Nasional Indonesia, dalam Fatwa DSN-MUI No. 40/DSN-MUI/2003, telah merumuskan bahwa jual beli saham adalah boleh dilakukan.

\section{Instrumen Pasar Modal dan Saham Syari’ah di Indonesia}

Instrumen pasar modal syari'ah dapat dikelompokkan menjadi tiga kategori, yakni; (Gufron, 2005: 27)

1. Sekuritisasi aset/ proyek aset (asset securitisation) yang merupakan bukti penyertaan, baik dalam bentuk penyertaan musyarakah (management share) maupun penyertaan mudharabah (participation share).

2. Sekuritisasi hutang (debt securisation).

3. Sekuritisasi modal. Merupakan emisi surat berharga oleh perusahaan emiten yang telah terdaftar dalam pasar modal syari'ah dalam bentuk saham.

Instrumen saham syari'ah terdiri dari saham, emiten, pasar primer, dan pasar sekunder. Ada beberapa kaidah yang harus dipenuhi oleh instrumen saham syari'ah ini, yakni: (Manan, 2010: 302-303)

1. Kaidah syari'ah untuk saham:

1.1. Bersifat musyarakah jika saham ditawarkan secara terbatas.

1.2. Bersifat mudharabah jika saham ditawarkan secara publik. 
1.3. Tidak boleh ada pembedaan jenis saham karena risiko harus ditanggung oleh semua pihak.

1.4. Seluruh keuntungan akan dibagi hasil, dan jika terjadi kerugian akan dibagi rugi bila perusahaan dilikuidasi.

1.5. Investasi pada saham tidak dapat dicairkan kecuali setelah likuidasi.

2. Kaidah syari'ah untuk emiten:

2.1. Produk atau jasa yang dihasilkan harus dalam kategori halal

2.2. Hasil usaha tidak mengandung unsur riba dan tidak bersifat zalim.

2.3. Tidak menempatkan investor dalam kondisi gharar maupun maysir.

3. Kaidah syari'ah untuk pasar primer:

3.1. Semua akad harus berbasis pada transaksi yang riil atas produk dan jasa yang halal dan bermanfaat.

3.2. Tidak boleh menerbitkan efek utang untuk membayar kembali utang.

3.3. Dana hasil penjualan efek yang diterbitkan akan diterima oleh perusahaan.

3.4. Hasil investasi yang akan diterima pemodal merupakan fungsi dan manfaat yang diterima dari modal yang diperoleh dari dana hasil penjualan efek dan tidak boleh semata-mata merupakan fungsi dari waktu.

4. Kaidah syari'ah untuk pasar sekunder

4.1. Semua efek harus berbasis pada transaksi yang riil atas produk dan jasa yang halal.

4.2. Tidak boleh membeli efek utang dengan dana dari utang atau menerbitkan surat utang.

4.3. Tidak boleh membeli berdasarkan tren atau indeks.

4.4. Tidak boleh memperjualbelikan hasil yang diperoleh dari suatu efek walaupun efeknya sendiri dapat diperjualbelikan.

4.5. Tidak boleh melakukan transaksi murabahah dengan menjadikan objek transaksi sebagai jaminan.

4.6. Tidak boleh melakukan penawaran palsu dalam transaksi.

\section{Perbandingan antara Saham Syari'ah dan Saham Konvensional di Pasar Modal}

Ada beberapa perbandingan antara saham biasa (konvensional) dengan saham syari'ah di pasar modal (Rivai dkk, 2014: 247), antara lain: 
1. Saham dapat diperdagangkan kapan saja di pasar sekunder tanpa memerlukan persetujuan dari perusahaan yang mengeluarkan saham. Sedangkan saham syari'ah dengan kontrak mudharabah dan musyarakah ditetapkan berdasarkan persetujuan rabbul maal (investor) dan perusahaan sebagai mudharib untuk suatu periode tertentu.

2. Saham syari'ah seringkali dianggap tidak liquid karena batasan periode kontrak yang mengikat. Sedangkan saham konvensional lebih liquid dan atraktif karena dapat dijual kapan saja.

\section{Mekanisme Operasional Saham Syari'ah di Indonesia dan negara lain}

Prinsip-prinsip penyertaan modal secara syari'ah di Indonesia tidak diwujudkan dalam bentuk saham syari'ah ataupun non syari'ah, melainkan berupa pembentukan indeks saham yang memenuhi prinsip-prinsip syari'ah (Aziz, 2010: 97). Menurut Alhabshi, pasar modal syari'ah dalam konteks saham syari'ah pada dasarnya tidak boleh mengandung transaksi ribawi, transaksi gharar, dan juga tidak boleh bergerak pada sektor yang diharamkan oleh syari'ah. Pasar modal ini seharusnya bebas dari transaksi yang tidak beretika seperti manipulasi pasar, insider trading ${ }^{1}$, dan short selling ${ }^{2}$ (Umam, 2013: 128).

Transaksi pembelian dan penjualan saham di pasar modal syari'ah menurut Irfan Syauqi, tidak boleh dilakukan secara langsung dan dilarang dalam Islam. Hal tersebut dikarenakan pada penjualan saham di pasar modal konvensional, investor dapat membeli dan menjual saham secara langsung dengan menggunakan jasa broker atau pialang. Sehingga memungkinkan bagi para spekulan untuk mempermainkan harga. Hal ini mengakibatkan perubahan harga saham sudah ditentukan oleh kekuatan pasar, bukan karena nilai intrinsik saham itu sendiri lagi (Umam, 2013: 129). Oleh karena itu, emiten memberikan otoritas kepada agen di lantai bursa pada proses perdagangan saham syari'ah. Lalu agen tersebut bertugas mempertemukan antara emiten dan calon investor namun bukan untuk menjual dan membeli saham secara langsung. Pada tahapan berikutnya, saham tersebut dijual atau dibeli karena sahamnya memang tersedia dan berdasarkan prinsip first come -first served (Umam, 2013: 129).

\footnotetext{
${ }^{1}$ Insider trading merupakan jenis transaksi yang memanfaatkan informasi orang dalam untuk memperoleh keuntungan atas transaksi yang dilarang.

${ }^{2}$ Short selling merupakan penjualan saham yang belum dimiliki dan membelinya belakangan.
} 


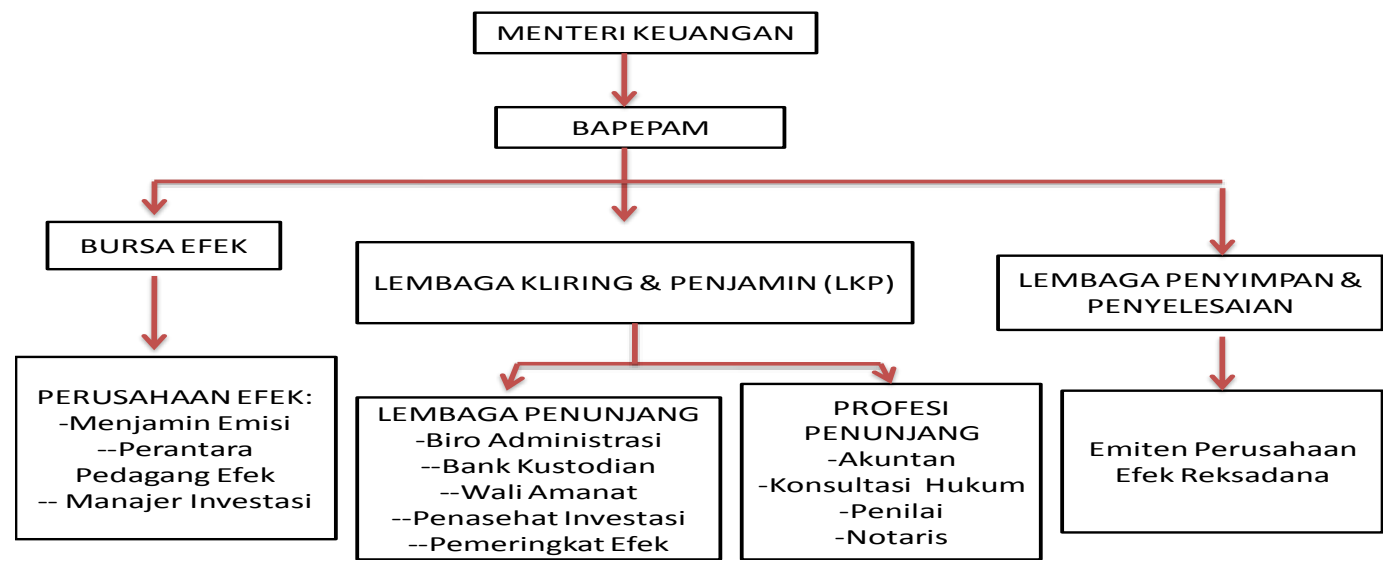

Skema diatas merupakan skema struktur pasar modal di Indonesia. Struktur pasar modal tersebut terdiri dari: (Soemitra, 2009: 119-121)

1. Bapepam

Bapepam merupakan lembaga pengawas pasar modal yang bertugas untuk membina, mengatur, dan mengawasi kegiatan sehari-hari di pasar modal. Bapepam ini berada di bawah tanggung jawab menteri keuangan.

2. Bursa efek

Bursa efek adalah pihak yang menyelenggarakan dan menyediakan sistem dan sarana untuk mempertemukan penawaran jual dan beli efek antara emiten dan investor.

3. Lembaga Kliring dan Penjaminan

Lembaga kliring dan penjaminan adalah pihak yang menyelenggarakan jasa kliring dan penjamin penyelesaian transaksi bursa.

4. Lembaga Penyimpan dan Penyelesaian

Lembaga penyimpan dan penyelesaian berfungsi sebagai penyedia layanan kustodian sentral dan penyelesaian transaksi yang teratur, wajar, dan efisien.

Proses penawaran umum pada pasar modal terdiri dari proses emisi dan perdagangan di bursa efek. Pada proses emisi, Perusahaan mengajukan permohonan pendaftaran kepada Bapepam di Jakarta melalui penjamin emisi (underwriter), dengan melampirkan:anggaran dasar/ akte pendirian perusahaan, prospektus, laporan keuangan yang telah diaudit, perjanjian emisi efek, comfort letter, legal opinion, serta dokumendokumen lain yang dibuat dalam rangka emisi. Apabila menurut hasil evaluasi bapepam perusahaan tersebut telah memenuhi persyaratan untuk go public maka proses terakhir 
yang harus dilakukan adalah pendapat akhir yang bersifat terbuka untuk umum (Gufron, 2005: 31).

Selanjutnya adalah perdagangan di bursa efek, yakni pencatatan efek-efek dari perusahaan yang wajib dicatat di bursa efek untuk diperdagangkan. Transaksi dilakukan oleh perantara perdagangan efek. Mekanisme perdagangan disini terdiri dari pasar primer dan pasar sekunder. Pasar primer merupakan transaksi antara emiten dan investor sebelum saham-saham diperdagangkan di pasar sekunder. Harga saham merupakan harga pasti yang tidak bisa ditawar dan merupakan kesepakatan antara perusahaan penjamin emisi dan emiten.Ada beberapa tahap penawaran saham pada pasar perdana, yakni: (Gufron, 2005: 31-34).

1. Pengumuman dan Pendistribusian Prospektus

2. Masa Penawaran

3. Masa Penjatahan

4. Masa Pengembalian Dana

5. Penyerahan Efek

6. Pencatatan Efek

Sedangkan pada pasar sekunder, perdagangan terjadi ketika perdagangan saham sudah melewati masa penawaran umum di pasar perdana, dan saham-saham tersebut telah tercatat di bursa efek untuk diperdagangkan. Harga saham di pasar sekunder sangat ditentukan oleh teori permintaan dan penawaran serta kondisi perusahaan yang menerbitkan saham (emiten). Harga saham disini adalah harga jual saham dari satu investor kepada investor yang lainnya (Gufron, 2005: 35). Harga saham yang ditawarkan pada kedua pasar ini berbeda dan pada mayoritasnya harga saham di pasar sekunder lebih tinggi dibandingkan dengan pasar perdana. Oleh karena itu perdagangan saham di pasar sekunder lebih mendekati pada unsur spekulasi dengan risiko tinggi yang mengandung unsur gambling yang dilarang dalam Islam (Aziz, 2010: 95).

Perdagangan saham di pasar sekunder sangat dipengaruhi oleh unsur insider trading. Hal ini menyebabkan terjadinya kompetisi yang tidak sehat di kalangan investor. Sikap insider trading ini sama dengan yang dilakukan oleh orang-orang kota ketika melakukan transaksi dengan mendatangi langsung orang-orang desa, yang di dalamnya terdapat unsur penipuan karena orang desa (produsen) belum mengetahui secara pasti harga komoditas yang sebenarnya (Umam, 2013: 96). Sedangkan 
mekanisme perdagangan saham di pasar perdana masih merupakan perdagangan biasa, yang selembar sahamnya diperdagangkan sesuai dengan kualitas yang masih wajar. ${ }^{3}$

Berbeda dengan mekanisme perdagangan saham secara konvensional, mekanisme perdagangan saham syari'ah secara spesifik dipertemukan pada Jakarta Islamic Index (JII) dan penawarannya hanya pada pasar perdana. Hal ini dilakukan dengan tujuan agar tidak ada lagi unsur-unsur spekulasi dan sikap insider trading, sebagaimana yang terjadi pada pasar sekunder selama ini (Aziz, 2010: 96).

Jakarta Islamic Index dimaksudkan untuk digunakan sebagai tolak ukur untuk mengukur kinerja suatu investasi pada saham yang berbasis syari'ah. Melalui JII tersebut diharapkan dapat meningkatkan kepercayaan investor untuk mengembangkan investasi dalam ekuiti secara syari'ah. Penerbitan saham syari'ah oleh emiten atau perusahaan publik yang menyatakan bahwa kegiatan usaha serta pengelolaannya dilakukan berdasarkan prinsip syari'ah di pasar modal. Emiten dan perusahaan publik tersebut wajib mengikuti ketentuan umum pengajuan pertanyaan pendaftaran atau pedoman mengenai bentuk dan isi pertanyaan pendaftaran perusahaan publik serta ketentuan tentang penawaran umum yang terkait lainnya yang diatur oleh Bapepam LK dan mengungkapkan informasi tambahan dalam prospektus bahwa kegiatan usaha serta cara pengelolaan usahanya berdasarkan prinsip-prinsip syari'ah di pasar modal (Soemitra, 2009: 139).

Secara umum, perusahaan yang akan menerbitkan efek syari'ah harus memenuhi ketentuan sebagai berikut: (Soemitra, 2009: 139-140)

1. Memuat ketentuan bahwa kegiatan usaha serta cara pengelolaan usaha dilakukan berdasarkan prinsip-prinsip syari'ah di pasar modal di dalam anggaran dasarnya.

2. Semua jenis usaha, akad, aset yang dikelola, cara pengelolaan oleh emiten, produk dan jasanya tidak boleh bertentangan dengan prinsip-prinsip syari'ah.

3. Emiten dan perusahaan publik tersebut memiliki anggota direksi dan komisaris yang mengerti dan paham mengenai kegiatan-kegiatan yang bertentangan dan tidak bertentangan dengan prinsip syari'ah.

Dalam perkembangannya, Malaysia dan Amerika Serikat telah melakukan pembatasan terhadap suatu saham yang dapat dikategorikan sebagai saham syari'ah melalui Dow Jones Islamic Index. Sementara itu beberapa institusi keuangan dunia

\footnotetext{
${ }^{3}$ Saham ditawarkan dengan mengajukan harga tertentu yang ditetapkan berdasarkan keadaan perusahaan dan kekuatan pasar.
} 
telah membuat juga batasan-batasan untuk kategori saham syari'ahnya melalui Citi Asset Management Group, Wellington Management Company, Islamic.com, dan lain sebagainya (Alma, 2009: 45).

Pada saham syari'ah dikenal dengan istilah proses pemurnian pendapatan non halal. Proses pemurnian ini dilakukan hanya pada perusahaan yang halal namun diragukan pada pendapatan non halalnya. Metode yang digunakan adalah sebagai berikut: (Gufron, 2005: 42-44).

\section{Metode I}

Total pendapatan

200 juta

Pendapatan non halal

20 juta

Cleasing factor $=10 \%$

Jika perusahaan mendapatkan capital gain

Rp 5.000.000

Cleasing factor $10 \%$ dari capital gain

$\frac{\operatorname{Rp} 500.000}{\operatorname{Rp} 5.500 .000}$

Pendapatan halal

Jika pada dividen:

Dividen

Rp 2.000.000

Cleasing factor $10 \%$

$\operatorname{Rp} 200.000$

Dividen halal

Rp 1.800 .000

\section{Perkembangan Saham Syariah di Indonesia dan Negara Lain}

Saham yang terdaftar di pasar modal tidak semuanya memenuhi prinsip syari’ah. Oleh karena itu Bursa Efek bekerjasama dengan Danareksa Investment Management dengan mengembangkan suatu indeks untuk menyaring saham-saham yang layak dianggap memenuhi prinsip-prinsip syari'ah. Indeks ini disebut juga dengan Jakarta Islamic Indeks (JII) (Rivai, dkk, 2014: 247).

Saham yang dikategorikan mendekati prinsip syari'ah adalah saham perusahaan yang tidak terkait dengan aktivitas haram seperti riba, gharar, judi, pornografi, memproduksi serta memperjualbelikan minuman keras, rokok, dan lain sebagainya. Di Indonesia, saham-saham yang memenuhi prinsip syari'ah baik dari segi jenis maupun operasional usahanya tergabung dalam Jakarta Islamic Index (JII) dan diperdagangkan 
di Bursa Efek. Investor yang memiliki kemampuan sendiri berinvestasi langsung ke instrumen saham dan dapat memilih saham di dalam daftar JII tersebut.

Saham-saham yang memenuhi kriteria indeks saham syari'ah adalah emiten yang kegiatan usahanya tidak bertentangan dengan syari'ah seperti:

1. Usaha perjudian dan permainan yang tergolong judi atau perdagangan yang dilarang oleh syari'ah.

2. Usaha lembaga keuangan konvensional termasuk perbankan dan asuransi yang beroperasi secara konvensional.

3. Usaha yang memproduksi, mendistribusi serta memperdagangkan makanan dan minuman yang tergolong haram berdasarkan hukum Islam.

4. Usaha yang memproduksi, mendistribusi, atau menyediakan barang-barang ataupun jasa yang merusak moral dan bersifat merugikan.

Selain kriteria di atas, dalam proses pemilihan saham yang akan masuk ke JII, Bursa Efek Jakarta melakukan tahap-tahap pemilihan yang juga mempertimbangkan aspek likuiditas dan kondisi keuangan emiten, yaitu: (Manna, 2010: 300).

1. Memilih kumpulan saham dengan jenis usaha utama yang tidak bertentangan dengan prinsip syari'ah dan sudah tercatat lebih dari 3 bulan.

2. Memilih saham berdasarkan laporan keuangan tahunan atau tengah tahun berakhir yang memiliki rasio kewajiban terhadap aktiva maksimal sebesar 90\%.

3. Memilih 60 saham dari susunan saham di atas berdasarkan urutan rata-rata kapitalisasi pasar terbesar selama satu tahun terakhir.

4. Memilih 30 saham dengan urutan berdasarkan tingkat likuiditas rata-rata nilai perdagangan reguler selama satu tahun terakhir.

Perkembangan pasar modal syari'ah di Indonesia khususnya pada saham syari'ah belum menggambarkan perkembangan yang cukup baik jika dibandingkan dengan perkembangannya di Malaysia. Walaupun JII sudah bekerja dengan cukup baik, Indonesia masih sangat jauh tertinggal dalam pengembangan kegiatan investasi syari'ah dipasar modal (Aziz, 2010: 99).

Malaysia sudah sejak tahun 1990 mengembangkan kegiatan investasi syari'ah di pasar modal dan terus berkembang dengan pesat. Sedangkan Indonesia memulai hal yang sama pada pertengahan tahun 1997. Pada akhir tahun 2002 Malaysia telah memiliki 36 reksa dana syari'ah dari total 174 Reksa Dana yang ada di Malaysia dan 
total nilai aktiva bersih (NAB) tersebut mencapai 5\% dari total NAB reksa dananya. Sementara Indonesia baru memiliki 10 Reksa Dana syari'ah dari total 223 reksa dana yang ada di pasar modal pada awal November 2004 dengan NAB sebesar 0,32\% dari keseluruhan NAB reksa dana yang ada di Indonesia (Aziz, 2010: 99-100).

\section{Contoh Kasus Saham Syari'ah}

Ada beberapa contoh kasus pada saham syari'ah. Kasus ini terjadi karena pertentangan antara teori dan praktik pada saham syari'ah sendiri serta pertentangan dengan prinsip-prinsip syari'ah. Kasus-kasus tersebut antara lain:

1. Saham syari'ah yang boleh masuk ke JII disyaratkan memiliki nilai ketidakhalalan (haram/riba) maksimal sebesar 15\%. Hal ini sangat bertentangan dengan prinsipprinsip syari'ah.

2. Pada proses jual beli saham syari'ah, para pemain saham akan membeli saham jika harga saham sedang turun dan akan menjualnya pada saat harga naik. Hal ini bertentangan dengan nilai-nilai etika dalam Islam. Islam juga melarang untuk menikmati keuntungan diatas kerugian orang lain. Pada prinsipnya, saham itu nilainya adalah 1:1. Jika salah satu pihak mendapatkan keuntngan maka pihak lainnya akan mengalami kerugian. Begitu seterusnya. Sehingga keberadaan saham syari'ah ini juga masih dalam perdebatan para ulama.

3. Pada saham syari'ah, sebagian investor sengaja melempar harga saham sehingga harganya menjadi jatuh karena terlalu banyak penawaran. Pemilik saham yang kecil kemudian segera menjual kembali saham dengan harga yang sangat murah karena khawatir harga saham tersebut akan semakin jatuh dan mereka semakin rugi. Pada akhirnya harga saham akan terus turun. Pada saat itu para investor besar akan berkesempatan untuk membelinya kembali dengan harga yang sangat murah dengan harapan akan bisa meninggikan kembali harga saham tersebut dengan banyaknya permintaan. Hal ini menyebabkan para investor besar tersebut mengalami keuntungan yang sangat besar dan para investor kecil lah yang menanggung kerugiannya dikarenakan perbuatan para investor besar yang berpurapura melempar kertas saham (Al-Mushlih, dkk, 2004: 295-296).

Perdebatan mengenai keberadaan efek syari'ah ini berdasarkan pada kekhawatiran bahwa pasar ini akan menyebabkan hilangnya modal besar-besaran dalam waktu 
singkat dan di sisi lain akan menyebabkan munculnya orang kaya baru yang tanpa mengeluarkan keringat. Hal ini akan menyebabkan terjadinya ketidakseimbangan pasar dalam perekonomian.

Di pasar modal, larangan syariah diatas mesti diimplementasikan dalam bentuk aturan main yang mencegah praktek spekulasi, riba, gharar, dan maysir. Salah satunya adalah dengan menetapkan minimum holding period atau jangka waktu memegang saham minimum. Dengan aturan ini, saham tidak bisa diperjualbelikan setiap saat, sehingga meredam motivasi mencari untung dari pergerakan harga saham semata. Pembatasan ini memang meredam spekulasi tetapi juga membuat investasi di pasar modal menjadi tidak liquid. Padahal tidak mungkin seorang investor yang rasional betul-betul membutuhkan likuiditas mendadak sehingga harus mencairkan sahamnya yang dipegangnya, sedangkan ia terhalang belum lewat masa minimum holding period-nya. Metwally mengusulkan minimum holding period setidaknya satu pekan. Selain itu, Ia juga memandang perlu adanya celling price berdasarkan nilai pasar perusahaan. Lebih lanjut Akram Khan melengkapi, untuk mencegah spekulasi di pasar modal maka jual beli saham harus diikuti dengan serah terima bukti kepemilikan saham yang diperjualbelikan (Huda, dkk, 2008: 78-82).

4. Mengenai keberadaan pasar sekunder. Pada hakikatnya, saham syari'ah tidak memiliki pasar sekunder karena dikhawatirkan akan berdampak pada spekulasi. Namun dalam praktiknya, saham syari'ah tetap menggunakan pasar sekunder sebagai instrumennya.

\section{SIMPULAN}

Saham syari'ah merupakan salah satu instrumen dalam pasar modal syari'ah yang dijalankan berdasarkan prinsip-prinsip syari'ah. Mekanisme operasional dari saham syari'ah terdiri dari proses emisi dan perdagangan di bursa efek. Perdagangan di bursa efek ini terdiri dari perdagangan di pasar primer dan pasar sekunder. Pada pasar primer, harga saham bersifat pasti. Berbeda dengan pasar sekunder yang harga sahamnya bersifat fluktuatif berdasarkan demand dan suply serta perusahaan yang menerrbitkan saham sendiri. 
Perbedaan mendasar antara saham konvensiional dan saham syari'ah adalah saham syari'ah harus masuk ke dalam JII (Jakarta islamic Index). Terjadi perdebatan ulama dan ekonom mengenai keberadaan pasar sekunder. Pasar sekunder dianggap berdampak menimbulkan tindakan kecurangan dan spekulatif. Namun dalam praktiknya pasar sekunder di saham syari'ah tetap dibutuhkan.

\section{DAFTAR PUSTAKA}

\section{Buku}

Al-Mushlih, Abdullah, dkk, Fikih Ekonomi Keuangan Islam, Penj. Abu Umar Basyir, Jakarta: Darul Haq, 2004.

Alma, Buchari, dkk, Manajemen Bisnis Syariah, Bandung: ALFABETA, 2009.

Aziz, Abdul, Manajemen Invetasi Syari'ah, Bandung: Penerbit Alfabeta, 2010.

Ghufron, Sofiniyah (Peny.), Briefcase Book Edukasi Profesional Syariah: Sistem Kerja Pasar Modal Syariah, Jakarta: Renaisan, 2005.

Huda, Nurul, dkk, Investasi Pada Pasar Modal Syariah, Jakarta: Kencana, 2008.

Manan, Abdul, Hukum Ekonomi Syariah: Dalam Perspektif Kewenangan Peradilan Agama, Jakarta: Kencana, 2012.

Rivai, Veithzal, dkk, Islamic Economics: Ekonomi Syariah Bukan Opsi, tetapi Solusi!, Jakarta: Bumi Aksara, 2009.

Rivai, Veithzal, dkk, Principle of Islamic Finance (Dasar-Dasar Keuangan Islam): Saatnya Hijrah ke Sistem Keuangan Islam yang Telah Teruji Keampuhannya, Cet. 2, Yogyakarta: BPFE, 2014.

Soemitra, Andi, Bank dan Lembaga Keuangan Syariah, Jakarta: Kencana, 2009.

Sotari, DjamdanaanKomariah, MetodologiPenelitianKualitatif, Bandung: PT. Alfabeta.2009.

Umam, Khaerul, Pasar Modal Syari'ah dan Praktik Pasar Modal Syariah, Bandung: CV. Pustaka Setia, 2013.

Yuliana, Indah, Investasi Produk Keuangan Syariah, Malang: UIN Maliki Malang Press, 2010.

\section{Skripsi}

Skripsi Adisi Sharesia Rusena, Analisis Fundamental Dan Teknikal Padasaham Syariah Di Indonesia (Studi Empiris: Perusahaan yang Masuk dalam JII dan ISSI di Bursa Efek Indonesia Tahun 2011-2015). UIN Syarif Hidayatullah, 2015. 
82 | Choirunnisak. Saham Syariah; Teori dan Implementasi

Skripsi Ayu Syintia, Analisis Integrasi Indeks Harga Saham Syariah Pada Pasar Modal Syariah Indonesia, Malaysia, China, dan Jepang (Periode Mei 2011-Desember 2016.Universitas Raden Intan Lampung, 2018. 